\title{
Management of Root-Knot Nematodes (Meloidogyne spp.) Using Different Bio-Agents in Papaya Nursery
}

\author{
Nesal A. Patel* and Ashok D. Patel \\ College of Agriculture and Polytechnic in Agriculture, Anand Agricultural University, \\ Vaso-387380, Dist. Kheda, Gujarat, India \\ *Corresponding author
}

\section{A B S T R A C T}

\begin{tabular}{|l|}
\hline K e y w o r d s \\
$\begin{array}{l}\text { Papaya, root-knot } \\
\text { nematode, } \text { Pseudomonas } \\
\text { putida, } \text { P. fluorescens, } \\
\text { Bacillus } \\
\text { amyloliquefaciens, } B . \\
\text { pumilus, } \text { B. subtilis, } B . \\
\text { megaterium and } \\
\text { Purpureocillium } \\
\text { lilacinum }\end{array}$ \\
\hline Article Info \\
\hline $\begin{array}{l}\text { Accepted: } \\
15 \text { July } 2019 \\
\text { Available Online: } \\
\text { 10 August } 2019\end{array}$ \\
\hline
\end{tabular}

Introduction

Papaya (Carica papaya Linn.) is a tropical fruit having commercial importance because of its high nutritive and medicinal value. Sudhakar (2014) opined that C. papaya is commonly called as paw-paw and it belongs to the family Caricaceae. Papaya fruit is a rich source of vitamin A and C. Papain prepared from dried latex of its immature fruits is used in manufacturing of chewing gum, cosmetics, degumming natural silk and to give shrink resistance to wool. It is also used in pharmaceutical industries, textile and garment, cleaning paper and adhesive manufacture,
Various methods are used to manage phytonematodes under field conditions. Use of chemicals to manage phytonematodes in various crops is very popular among farmers. But these chemicals are not ecofriendly. Various bio-control agents are found promising against root-knot nematodes. Therefore to study the effect of different bio-agents for the management of Meloidogyne spp. in papaya nursery, application of Pseudomonas putida, P. fluorescens, Bacillus amyloliquefaciens, B. pumilus, B. subtilis, B. megaterium and Purpureocillium lilacinum each @ $50 \mathrm{~g} / \mathrm{m}^{2}$ were tested in nursery having initial nematode population of 293 $\mathrm{J}_{2} / 200 \mathrm{~cm}^{3}$ soil. During experiment we have taken different observations viz., number of females, number of egg mass $/ 3 \mathrm{~g}$ roots and number of eggs/egg mass and transplantable seedlings of papaya. sewage disposal, etc. (Anon., 2016). Papaya cultivation had its origin in South Mexico and Costa Rica. It possesses excellent medicinal properties for treatment of different ailments. Growth, development and yield of papaya are highly influenced by various biotic stresses such as bacteria, fungi, viruses, insects and nematodes (Anon., 2014). Papaya is reported to be a good host of Meloidogyne spp. in many tropical and sub-tropical regions. It causes leaf yellowing and low leaf production as well as premature dropping of both leaves and fruits of papaya (Inserra and Cartia, 1977; Roy and Das, 1980 and Khan, 1989). Root-knot nematodes cause swelling and gall formation 
in the roots, which prevent water and nutrient uptake. Nematode population may be high in papaya without producing symptoms. Heavy nematode infestations can cause wilting, stunting, decreased plant vigor, reduced yields and shortening of the productive life of a papaya tree (Anon., 2008).

Khan et al., (1997) observed beneficial effects of Paecilomyces lilacinus and Trichoderma harzianum when applied against $M$. incognita and Fusarium solani on potted papaya in steam sterilized soil. The combined effect of both the biocontrol agents was more effective than individual biocontrol agents in reducing nematodes and decreasing the incidence of root rot.

Rao (2007) concluded that seed treatment with Pseudomonas fluorescens $\left(10^{8} \mathrm{cfu} / \mathrm{g}\right)$ and application of $P$. fluorescens and $T$. harzianum $\left(10^{6} \mathrm{cfu} / \mathrm{g}\right)$, each at $5 \mathrm{~g} / \mathrm{kg}$ soil, significantly reduced eggs/egg mass of $M$. incognita in papaya seedlings.

Kumar (2009) carried out an experiment to manage $M$. incognita in papaya with Pochonia chlamydosporia and noticed that nematode population was significantly low on $30^{\text {th }}$ day when applied @ $5 \mathrm{~kg} / \mathrm{ha}$. He also reported that $M$. incognita caused severe root galling and reduced plant growth and yield.

Pradhan et al., (2012) tested T. harzianum, neem oil and carbofuran $5 \mathrm{G}$ against root-knot nematode ( $M$. javanica) in two papaya varieties Kashempuri and Deshi papaya. Seedlings were inoculated with $M$. javanica. Neem oil ( $5 \mathrm{ml} / 10 \mathrm{~g}$ seeds) and $T$. harzianum (1:4) were used as seed treatment. $T$. harzianum significantly increased the root and shoot growth, reduced galls and egg masses and suppressed the development of $\mathbf{J}_{2}, \mathbf{J}_{3}$, and $\mathrm{J}_{4}$ and adult females.

Singh et al., (2013) investigated 24 indigenous isolates of $P$. lilacinum (Paecilomyces lilacinus) (Thom) Samson against the $M$. incognita collected from different agroclimatic zones of India. Results showed that all the tested isolates were capable to parasitise eggs, inhibit egg hatching and caused juvenile mortality at various levels. Based on the performance under studies, out of eight isolates (NDPL-01, ANDPL-02, SHGPL-03, HYBPL-04, AHDPL-05, PTNPL06, SNGPL-07 and VNSPL-08), HYBPL-04 caused highest mortality $(80 \%)$, inhibition of egg hatching $(90 \%)$ as well as parasitisation of $M$. incognita eggs $(75 \%)$, in terms of reduction of galls $(61 \%)$ and reproductive factor $(\mathrm{Pf} / \mathrm{Pi}(\mathrm{RF})=0.2)$ achieved through application of HYBPL-04 + FYM compared to control and other tested isolates.

Nematicidal activity of Bacillus subtilis, $B$. megaterium, B. pumilus and P. fluorescens, $T$. harzianum, $T$. viride and $T$. virens against nematode population of $M$. incognita infecting tropical fruit, studied by Youssef et al., (2017). Results showed that $T$. virens reduced the gall numbers by $74 \%$ followed by $B$. pumilus (73\%), T. viride (73\%), B. subtilis and T. harzianum (71\%), B. megaterium $(71 \%)$ and $P$. fluorescens $(60 \%)$. T. virens also caused highest percentage reduction of eggmasses $(80 \%)$ followed by B. pumilus, $T$. harzianum and $T$. viride that caused $74 \%$, $68 \%, 65 \%$ and $61 \%$ reduction by $B$. megaterium, B. subtilis and P. fluorescens, respectively. $T$. virens when applied at one and/or second time was effective in enhancing the growth parameters viz., length of shoot, fresh and dry weight of shoot and root weight than B. pumilus. Walia and Khan (2018) reported control of root-knot nematode population and their galling density by applying $P$. chlamydosporia @ $5 \mathrm{~kg} / \mathrm{ha}$ in papaya field. Enrichment of FYM with biopesticides@2 kg each of $P$. lilacinus, $P$. fluorescens and $T$. harzianum/T. viride in one ton of FYM and kept it in shade for 15 days at $25-30 \%$ moisture for multiplication of 
beneficial microbes and controlling root-knot nematode population in nursery bed of papaya.

\section{Materials and Methods}

Bio-agents were applied with $250 \mathrm{~g}$ FYM before sowing in $1.2 \times 1.2 \mathrm{~m}$ Meloidogyne spp. infested bed for the management of root knot nematodes. Seeds of papaya $c v$. Madhubindu were sown at $15 \times 10 \mathrm{~cm}$ spacing in furrows of bed. Beds without any treatment were kept as untreated check. After 60 days of sowing, the experiment was discontinued by removing the seedlings from the nursery and roots were washed gently under running tap water and observations on fresh seedling weight and root-knot index were recorded. Roots were cut in to $2-3 \mathrm{~cm}$ length mixed thoroughly and three gram roots were stained in 0.05 per cent acid fuchsin in lactophenol. Then roots were washed with tap water to remove excess stain and kept overnight in lactophenol, Then the roots were examined for nematode population (Table 1 and 2).

\section{Results and Discussion}

\section{Germination count $/ 1.44 \mathrm{~m}^{2}$}

Data presented in table 3 revealed that the effect of various bio-agents on seed germination found non-significant indicated that the bio-agents used in present study have no adverse impact on seed germination.

\section{Fresh seedling weight (g)}

Seedlings raised in the beds treated with $P$. putida had maximum fresh seedling weight $(1048.33 \mathrm{~g})$ and it was statistically at par with P. lilacinum $\left(\mathrm{T}_{7}\right)$. B. amyloliquefaciens $\left(\mathrm{T}_{3}\right)$ was at third rank. Fresh seedling weight was lowest in the control $\left(\mathrm{T}_{8}\right)$. However, it was statistically at par with $B$. pumilus $\left(\mathrm{T}_{4}\right)$ and $B$. megaterium $\left(\mathrm{T}_{6}\right)$ (Table 3$)$.

\section{Transplantable seedlings (per $1.44 \mathrm{~m}^{2}$ )}

Significantly higher (79) transplantable seedlings were recorded in treatment of $P$. putida $\left(\mathrm{T}_{1}\right)$, followed by $B$. amyloliquefaciens $\left(\mathrm{T}_{3}\right)$, P. lilacinum $\left(\mathrm{T}_{7}\right)$, B. subtilis $\left(\mathrm{T}_{5}\right)$ and $P$. fluorescens $\left(\mathrm{T}_{2}\right)$, statistically all treatments found at par with each other. Lowest number of transplantable seedlings was noticed in the treatment of control $\left(\mathrm{T}_{8}\right)$ (Table 3$)$.

\section{Non-transplantable seedlings (per $1.44 \mathrm{~m}^{2}$ )}

Lowest number of non-transplantable seedlings (1) was noticed in P. putida $\left(\mathrm{T}_{1}\right)$ treatment followed by $B$. amyloliquefaciens $\left(\mathrm{T}_{3}\right)$, both were at par with each other. Significantly more number of nontransplantable seedlings i.e. 5 was found in control. Rest of the treatments registered nontransplantable seedlings ranging from 2 to 3 (Table 3).

\section{Root- knot index (RKI)}

Root-knot index was significantly least (1.59) in the treatment of $P$. putida $\left(\mathrm{T}_{1}\right)$, but it was at par with $P$. lilacinum $\left(\mathrm{T}_{7}\right)$ and $B$. amyloliquefaciens $\left(\mathrm{T}_{3}\right)$.Control $\left(\mathrm{T}_{8}\right)$ had significantly highest RKI as compared to other treatments. RKI of $B$. subtilis $\left(\mathrm{T}_{5}\right), \quad P$. fluorescens $\left(\mathrm{T}_{2}\right), B$. megaterium $\left(\mathrm{T}_{6}\right)$ and $B$. pumilus $\left(\mathrm{T}_{4}\right)$ were in the range of 1.92 to 2.05 and all were statistically at par with each other (Table 4).

\section{Final nematode population}

Data (Table 4) recorded on number of females from $3 \mathrm{~g}$ root indicated that treatment of $P$. putida $\left(\mathrm{T}_{1}\right)$ had significantly least (92) nematode population as compared to other treatments. 
Table.1 List of bio-agents tested

\begin{tabular}{|c|l|}
\hline Treatments code & \multicolumn{1}{|c|}{ Treatments } \\
\hline $\mathbf{T}_{\mathbf{1}}$ & Pseudomonas putida $\left(2 \times 10^{8} \mathrm{cfu} / \mathrm{g}\right) @ 50 \mathrm{~g} / \mathrm{m}^{2}$ \\
\hline $\mathbf{T}_{\mathbf{2}}$ & Pseudomonas fluorescens $\left(2 \times 10^{8} \mathrm{cfu} / \mathrm{g}\right) @ 50 \mathrm{~g} / \mathrm{m}^{2}$ \\
\hline $\mathbf{T}_{\mathbf{3}}$ & Bacillus amyloliquefaciens $\left(2 \times 10^{8} \mathrm{cfu} / \mathrm{g}\right) @ 50 \mathrm{~g} / \mathrm{m}^{2}$ \\
\hline $\mathbf{T}_{\mathbf{4}}$ & Bacillus pumilus $\left(2 \times 10^{8} \mathrm{cfu} / \mathrm{g}\right) @ 50 \mathrm{~g} / \mathrm{m}^{2}$ \\
\hline $\mathbf{T}_{\mathbf{5}}$ & Bacillus subtilis $\left(2 \times 10^{8} \mathrm{cfu} / \mathrm{g}\right) @ 50 \mathrm{~g} / \mathrm{m}^{2}$ \\
\hline $\mathbf{T}_{\mathbf{6}}$ & Bacillus megaterium $\left(2 \times 10^{8} \mathrm{cfu} / \mathrm{g}\right) @ 50 \mathrm{~g} / \mathrm{m}^{2}$ \\
\hline $\mathbf{T}_{\mathbf{7}}$ & Purpureocillium lilacinum $\left(2 \times 10^{8} \mathrm{cfu} / \mathrm{g}\right) @ 50 \mathrm{~g} / \mathrm{m}^{2}$ \\
\hline $\mathbf{T}_{\mathbf{8}}$ & Control (Untreated check) \\
\hline
\end{tabular}

Table.2 Root-knot Index Scale

\begin{tabular}{|c|c|c|}
\hline \multicolumn{3}{|c|}{ Rating scale (0-5), per cent root infection and reaction pertaining to root-knot nematodes } \\
\hline Root Knot Index (RKI) & Per cent root infection & Reaction \\
\hline 0 & No galling & Highly resistant \\
\hline $\mathbf{0 . 0 1 - 1 . 0}$ & Up to 20\% root galling & Resistant \\
\hline $\mathbf{1 . 0 1 - 2 . 0}$ & Up to $40 \%$ root galling & Moderately resistant \\
\hline $\mathbf{2 . 0 1 - 3 . 0}$ & Up to 60\% root galling & Moderately susceptible \\
\hline $\mathbf{3 . 0 1 - 4 . 0}$ & Up to $80 \%$ root galling & Susceptible \\
\hline $\mathbf{4 . 0 1 - 5 . 0}$ & More than $80 \%$ root galling & Highly susceptible \\
\hline
\end{tabular}

Table.3 Effect of different bio-agents on plant growth characters of papaya

\begin{tabular}{|c|c|c|c|c|}
\hline Treatments & $\begin{array}{l}\text { Germination } \\
\text { count } / 1.44 \mathrm{~m}^{2}\end{array}$ & $\begin{array}{l}\text { Fresh seedling } \\
\text { weight, } \mathrm{g}\end{array}$ & $\begin{array}{l}\text { Transplantable } \\
\text { seedlings } / 1.44 \mathrm{~m}^{2}\end{array}$ & $\begin{array}{c}\text { Non- } \\
\text { Transplantable } \\
\text { seedlings/1.44 } \mathrm{m}^{2}\end{array}$ \\
\hline $\mathbf{T}_{1}($ Pseudomonas putida $)$ & 80 & 1048.33 & 79 & 1 \\
\hline $\mathbf{T}_{2}$ (Pseudomonas fluorescens) & 79 & 670.67 & 77 & 2 \\
\hline $\mathbf{T}_{3}$ (Bacillus amyloliquefaciens) & 80 & 869.00 & 79 & 1 \\
\hline $\mathrm{T}_{4}$ (Bacillus pumilus) & 79 & 611.00 & 76 & 3 \\
\hline $\mathbf{T}_{5}$ (Bacillus subtilis) & 79 & 673.67 & 77 & 2 \\
\hline $\mathbf{T}_{6}($ Bacillus megaterium) & 78 & 650.00 & 75 & 3 \\
\hline $\mathbf{T}_{7}$ (Purpureocillium lilacinum) & 80 & 1000.00 & 78 & 2 \\
\hline $\mathbf{T}_{8}($ Control $)$ & 78 & 495.33 & 74 & 5 \\
\hline SEm \pm & 0.90 & 51.42 & 1.00 & 0.24 \\
\hline CD at $5 \%$ & NS & 155.97 & 3.02 & 0.72 \\
\hline $\mathrm{CV} \%$ & 1.97 & 11.79 & 2.24 & 15.80 \\
\hline
\end{tabular}

$$
\text { NS }=\text { Non-significant }
$$


Table.4 Effect of different bio-agents on multiplication of Meloidogyne spp. on papaya

\begin{tabular}{|c|c|c|c|c|c|c|}
\hline \multirow[t]{2}{*}{ Treatments } & \multirow{2}{*}{$\begin{array}{c}\text { RKI } \\
(\mathbf{0 - 5})^{*} \\
(\sqrt{ } \mathbf{x}+\mathbf{0 . 5})\end{array}$} & \multicolumn{5}{|c|}{ Nematode population } \\
\hline & & $\begin{array}{c}\text { No. of females/ } \\
3 \mathrm{~g} \text { root }(\mathrm{Log} \\
\mathrm{X}+1)\end{array}$ & $\begin{array}{l}\text { No. of egg mass/ } \\
\operatorname{root}(\log X+1)\end{array}$ & $\begin{array}{c}\text { No. of eggs/ } \\
\text { egg mass }(\log X+1)\end{array}$ & $\begin{array}{c}\text { No. of juveniles/ } \\
200 \mathrm{~cm}^{3} \text { soil (Log } \\
\text { X+1) }\end{array}$ & $\begin{array}{c}\text { Total } \\
(\log X+1)\end{array}$ \\
\hline $\mathrm{T}_{1}$ (Pseudomonas putida) & $\begin{array}{c}1.45 \\
(1.59)\end{array}$ & $\begin{array}{l}1.97 \\
(92)\end{array}$ & $\begin{array}{l}1.86 \\
(71)\end{array}$ & $\begin{array}{l}2.34 \\
(218)\end{array}$ & $\begin{array}{c}2.75 \\
(563)\end{array}$ & $\begin{array}{l}2.98 \\
(954)\end{array}$ \\
\hline $\mathbf{T}_{2}$ (Pseudomonas fluorescens) & $\begin{array}{c}1.94 \\
(3.26)\end{array}$ & $\begin{array}{l}2.39 \\
(243)\end{array}$ & $\begin{array}{l}1.92 \\
(82)\end{array}$ & $\begin{array}{c}2.45 \\
(281)\end{array}$ & $\begin{array}{c}3.57 \\
(3723)\end{array}$ & $\begin{array}{c}3.64 \\
(4364)\end{array}$ \\
\hline $\mathbf{T}_{3}$ (Bacillus amyloliquefaciens) & $\begin{array}{c}1.58 \\
(2.00)\end{array}$ & $\begin{array}{c}2.10 \\
(126)\end{array}$ & $\begin{array}{l}1.81 \\
(64)\end{array}$ & $\begin{array}{c}2.30 \\
(199)\end{array}$ & $\begin{array}{c}2.81 \\
(643)\end{array}$ & $\begin{array}{c}3.02 \\
(1046)\end{array}$ \\
\hline $\mathbf{T}_{4}$ (Bacillus pumilus) & $\begin{array}{c}2.05 \\
(3.69)\end{array}$ & $\begin{array}{l}2.44 \\
(276)\end{array}$ & $\begin{array}{l}1.92 \\
(82)\end{array}$ & $\begin{array}{l}2.46 \\
(287)\end{array}$ & $\begin{array}{c}3.57 \\
(3740)\end{array}$ & $\begin{array}{c}3.64 \\
(4364)\end{array}$ \\
\hline $\mathbf{T}_{5}$ (Bacillus subtilis) & $\begin{array}{c}1.92 \\
(3.19) \\
\end{array}$ & $\begin{array}{l}2.35 \\
(225)\end{array}$ & $\begin{array}{l}1.92 \\
(80)\end{array}$ & $\begin{array}{c}2.45 \\
(281)\end{array}$ & $\begin{array}{c}3.57 \\
(3723)\end{array}$ & $\begin{array}{c}3.63 \\
(4265) \\
\end{array}$ \\
\hline $\mathbf{T}_{6}($ Bacillus megaterium) & $\begin{array}{c}2.03 \\
(3.62)\end{array}$ & $\begin{array}{c}2.39 \\
(247)\end{array}$ & $\begin{array}{l}1.94 \\
(86)\end{array}$ & $\begin{array}{c}2.58 \\
(379)\end{array}$ & $\begin{array}{c}3.61 \\
(4101)\end{array}$ & $\begin{array}{c}3.68 \\
(4785)\end{array}$ \\
\hline $\mathbf{T}_{7}$ (Purpureocillium lilacinum) & $\begin{array}{c}1.57 \\
(1.96)\end{array}$ & $\begin{array}{c}2.18 \\
(150)\end{array}$ & $\begin{array}{l}1.88 \\
(75)\end{array}$ & $\begin{array}{c}2.40 \\
(250)\end{array}$ & $\begin{array}{l}2.97 \\
(926)\end{array}$ & $\begin{array}{c}3.15 \\
(1412)\end{array}$ \\
\hline $\mathbf{T}_{8}($ Control $)$ & $\begin{array}{c}2.28 \\
(4.70)\end{array}$ & $\begin{array}{c}2.59 \\
(386)\end{array}$ & $\begin{array}{l}1.97 \\
(92)\end{array}$ & $\begin{array}{c}2.59 \\
(388)\end{array}$ & $\begin{array}{c}3.68 \\
(4818)\end{array}$ & $\begin{array}{c}3.75 \\
(5622)\end{array}$ \\
\hline SEm \pm & 0.05 & 0.03 & 0.02 & 0.04 & 0.03 & 0.02 \\
\hline CD at $5 \%$ & 0.16 & 0.07 & 0.07 & 0.11 & 0.08 & 0.06 \\
\hline $\mathrm{CV} \%$ & 4.98 & 2.47 & 1.99 & 2.52 & 1.45 & 0.97 \\
\hline
\end{tabular}

$* 0=$ Free $; 5=$ Maximum disease intensity.

Figures in parentheses are retransformed values of transformation value 


\section{Effect of different bio-agents on papaya in nursery condition}

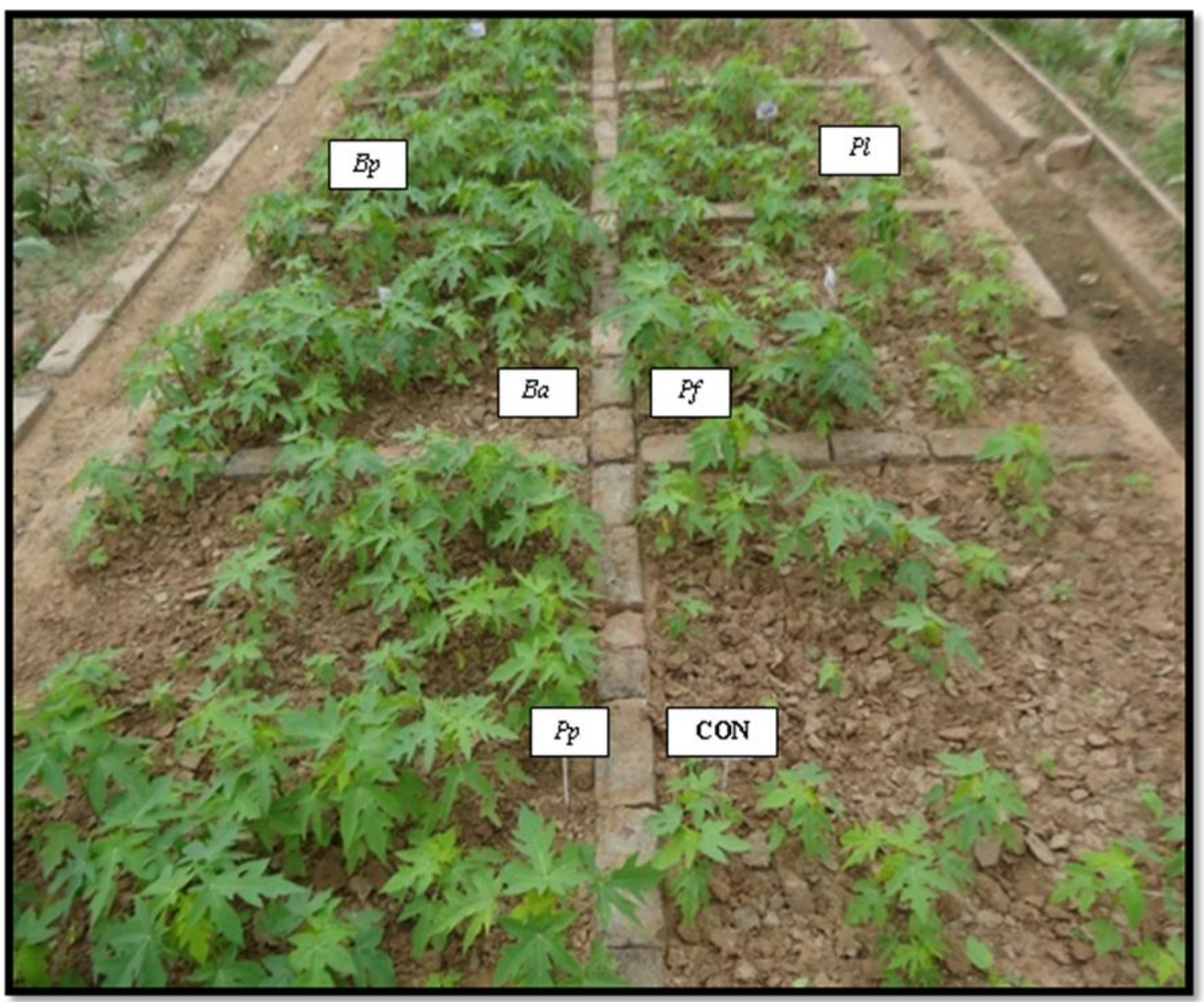

Treatment of B. amyloliquefaciens $\left(\mathrm{T}_{3}\right)$ found next best treatment followed by P. lilacinum $\left(\mathrm{T}_{7}\right)$. Control treatment had maximum population and similar trend was observed for number of egg mass/root and number of eggs/egg mass. Significantly least (563) number of nematode population from soil was recorded in the treatment of $P$. putida $\left(\mathrm{T}_{1}\right)$ followed by $B$. amyloliquefaciens $\left(\mathrm{T}_{3}\right)$, it was at par with each other. Untreated control had maximum nematode population and it was at par with B. megaterium $\left(\mathrm{T}_{6}\right)$ (Table 4$)$.

\section{Total nematode population}

In case of total nematode population, it was significantly least (954) in the treatment of $P$. putida $\left(\mathrm{T}_{1}\right)$ and found statistically at par with B. amyloliquefaciens $\left(\mathrm{T}_{3}\right)$, followed by $P$. lilacinum $\left(\mathrm{T}_{7}\right)$ and it was significantly differed with next best treatment. It is obvious that control had maximum (5622) nematode population (Table 4).

\section{References}

Anonymous (2008). ikisan, Agriculture Informatics and Services. Retrieved from (http://www.ikisan.com/tnPapaya-nematode-management.html)

Anonymous (2014). AESA based IPM package Papaya. National Institute of Plant Health Management. Department 
of Agriculture and Cooperation. Ministry of Agriculture, Govt. of India Anonymous (2016). TFNet- International Tropical Fruits Network. Retrieved from (www.itfnet.org/v1/2016/05/Papayaintroduction)

Inserra, R. M. and Cartia, G. (1977). Meloidogyne javanica su Papaya in Sicilia. Nematologia Mediterranea, 5, 137-139.

Khan, T. A. (1989). Studies on a disease complex of Papaya caused by Meloidogyne incognita and Fusarium solani, Annual progress report, D. S. T. Project, Department of Botany, Aligarh Muslim University, Aligarh, pp. 55

Khan, T. A., Khan, S. T., Fazal, M., and Siddiqui, Z. A. (1997). Biological control of Meloidogyne incognita and Fusarium solani disease complex in Papaya using Paecilomyces lilacinus and Trichoderma harzianum. International Journal of Nematology, 7, 127-132

Kumar, S. (2009). Management of root-knot nematode in Papaya by Pochonia chlamydosporia. Indian Journal of Nematology, 39 (1), 105-107

Pradhan, M. A. A., Rahaman, M. M., Paul, S. K., Ahmad M. U. and Goswami, B. K. (2012). Effect of BAU- bio fungicide, neem oil and a nematicide on the rootknot (Meloidogyne javanica) of Papaya (Carica papaya). Bangladesh Journal of Agricultural Research, 37 (2), 271277
Rao, M. S. (2007). Papaya seedling colonized by the bio-agents Tricoderma harzianum and Pseudomonas fluorescens to control root-knot nematode. Nematologia Mediterranea, 35 (2), 199-203

Roy, S. and Das, S. N. (1980). Plant parasitic nematodes associated with field and vegetable crops in Orissa. Journal of Research, QUATXL, pp.71-76

Singh, Saytandra, Pandey, Rajesh Kumar and Goswami, B. K. (2013). Bio-control activity of Purpureocillium lilacinum strains in managing root-knot disease of Tomato caused by Meloidogyne incognita. Biocontrol Science and technology, 23 (12), 1469-1489

Sudhakar, Natarajan (2014). Potential medicinal properties of Carica Papaya Linn. International Journal of Pharmacy and Pharmaceutical Sciences, 6 (2), 1-4

Walia, R. K. and Khan, M. R. (2018). A compendium of nematode diseases of crop plants. ICAR-All India Coordinated Research Project on Nematodes in Cropping Systems, New Delhi, India, pp. 62-63

Youssef, M. M. A., Abd-El-Khair, H. and ElNagdi, W. M. A. (2017). Management of root-knot nematode, Meloidogyne incognita infecting Sugar beet as affected by certain bacterial and fungal suspensions. Agricultural Engineering International: CIGR Journal, Special issue: 293-301.

\section{How to cite this article:}

Nesal A. Patel and Ashok D. Patel. 2019. Management of Root-Knot Nematodes (Meloidogyne spp.) Using Different Bio-Agents in Papaya Nursery. Int.J.Curr.Microbiol.App.Sci. 8(08): 1934-1940. doi: https://doi.org/10.20546/ijcmas.2019.808.227 